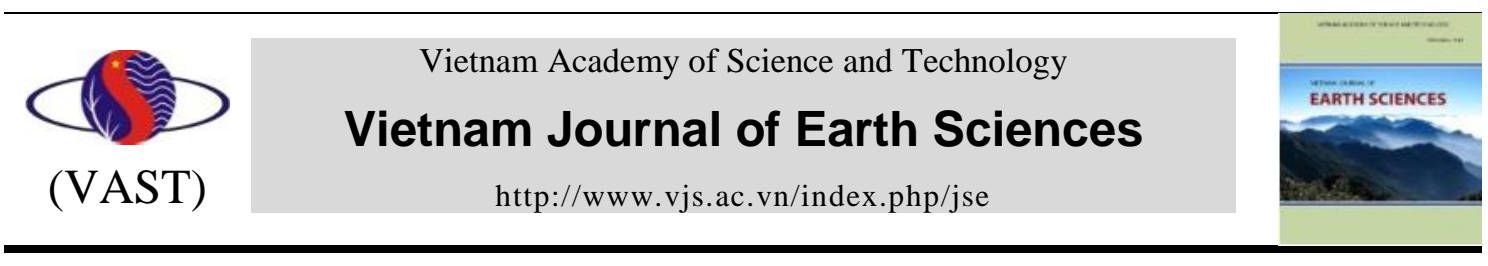

\title{
Trace elements and oxygen isotopes of gem spinels in marble from the Luc Yen - An Phu areas, Yen Bai province, North Vietnam
}

\author{
Pham Van Long* ${ }^{*}$, Gaston Giuliani², Anthony E. Fallick3, Andrian J. Boyce3, Vincent Pardieu4 \\ ${ }^{1}$ Institute for Gems and Gold Research of VINAGEMS (IGG), Hanoi, Vietnam \\ ${ }^{2}$ Université de Lorraine, IRD and CRPG UMR 7358 CNRS-UL, BP 20, 15 rue Notre-Dame-des-Pauvres, \\ 54501 Vandouvre-lès-Nancy, France \\ ${ }^{3}$ Isotope Geosciences Unit, S.U.E.R.C., Rankine Avenue, East Kilbride,Glasgow G75 OQF, Scotland, \\ United Kingdom \\ ${ }^{4}$ Field gemmologist, Bangkok, Thailand
}

Received 16 January 2018; Received in revised form 16 March 2018; Accepted 22 March 2018

\begin{abstract}
Trace elements investigated by electron microprobe analysis (EMPA) have been combined with oxygen isotopic composition of pink, red and other colored spinels (blue, purple, brown, orange, lavender) hosted by marbles and found in placers from Luc Yen and An Phu deposits, Yen Bai province, North Vietnam. The deposits are those from Nuoc Ngap, Cong Troi, Bai Son and different placers from the An Phu area. Trace elements such as Fe-Zn-Cr-V in red and pink gem spinels permit to separate those from Cong Troi and those from the others deposits of the An Phu area. Spinels from Cong Troi have low to extremely low Zn $(<500 \mathrm{ppm})$ and high Fe contents $(3,000$ to $16,000 \mathrm{ppm})$ while those from An Phu area are Zn-rich (up to 11,000 ppm). Iron is the dominant element for the other colored spinels whereas Zn, Cr and V contents are extremely variable. The Bai Son blue spinel is Fe-rich (5,000 to 7,200 ppm) with some V (950 to 1,830 ppm), Cr (270 to $480 \mathrm{ppm}$ ), Co (240 to $400 \mathrm{ppm}$ ) and Ni (550 to $950 \mathrm{ppm}$ ). The O-isotope composition of the whole spinels ranges between 12.1 and $24.2 \%$ o $(n=25)$. Within each deposit, the range of $\delta^{18} \mathrm{O}$ values for red, pink and colored spinels is usually similar. However, the red and pink spinels from An Phu present two distinct sets of $\delta^{18} \mathrm{O}$ values, respectively between 13.2 to $17.0 \%$ o $(\mathrm{n}=7)$ and $22.5<\delta^{18} \mathrm{O}<24.2(\mathrm{n}=5)$. Those from Cong Troi are from 14.8 to $17.7 \%$ o $(n=3)$ and their range overlaps that of An Phu. The use of O-isotopes is not useful for distinguishing between the deposits, but the low to extremely low $\mathrm{Zn}$ content of the Cong Trois spinels is a discriminant. The variation of $\delta^{18} \mathrm{O}$ values $\left(12.1<\delta^{18} \mathrm{O}<24.2 \%\right.$ o of the whole spinels indicates that the oxygen isotopic compositions of the metamorphic fluids were probably buffered by the local $\delta^{18} \mathrm{O}$ values of the impure host marbles.
\end{abstract}

Keywords: marble; gem spinel; trace elements; oxygen isotopes; geographic origin; Luc Yen - An Phu; Vietnam.

(C)2018 Vietnam Academy of Science and Technology

\section{Introduction}

Gem spinels have compositions close to $\mathrm{MgAl}_{2} \mathrm{O}_{4}$ sensustricto and the color depends

"Corresponding author, Email: long@ vinagems.vn on the incorporation in various proportions of bivalent and/or trivalent chromophores $\left(\mathrm{Fe}^{2+}\right.$, $\mathrm{Fe}^{3+}, \mathrm{Cr}$ and $\mathrm{V}$ ) in the octahedral and tetrahedral sites of the crystal structure. Spinel offers a wide palette of colours extending from pink 
to red, violet to purple tinges, orange brown to yellow, and also cobalt blue (Figure 1). World-famous and economic deposits of $\mathrm{Cr}$ $\mathrm{V}$-bearing red and pink spinels occur in Himalayan and East African marbles that have undergone high-temperature metamorphism (Pardieu \& Hughes 2008; Giuliani et al., 2017). Vietnam is the main producer of gem spinels found in primary (marble type) and secondary (placer) deposits. Spinel is exploited in small-scale mines and the most significant deposits are found in North Vietnam along the Red River Shear Zone (Huong et al., 2012; Pham et al., 2013). Vietnamese spinels have been investigated by different authors in terms of geological setting as for the discovery of the Lang Chap deposit in the Tan $\mathrm{Hu}$ ong-Truc Lau area (Malsy et al., 2012), gemmology (Pham et al., 2014), trace elements chemistry (Pham et al., 2004; Malsy\&Klemm, 2010; Kleišmantas\&Daukšyte, 2016; Giuliani et al;, 2017) and genesis (Hauzenberger et al., 2001; Chauviré et al., 2015).
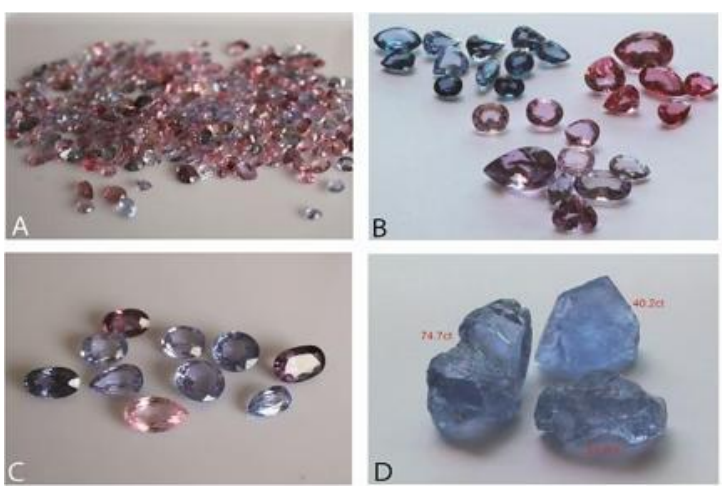

Figure 1. Spinels on the gem market of Luc Yen. A, B, C- Several gem cut coloured spinels. D- Three of rough sky blue spinels from Bai Son area. Photographs: Pham Van Long

The present study describes the use of trace elements and oxygen isotopic ratios $\left({ }^{18} \mathrm{O} /{ }^{16} \mathrm{O}\right)$ of lattice oxygen in pink and red spinels as well as other coloured varieties, to provide a gem geographic identification. This study differs from the previous paper devoted to the characterization of pink and red spinels hosted by marbles worldwide (Giuliani et al., 2017), when considering the following issues: (i) an update of spinel mining activities and types of deposits in the Luc Yen - An Phu areas; (ii) trace elements combined to oxygen isotopes exclusively to Vietnamese gem spinels; (iii) an in-depth discussion of the data to precise that the $\mathrm{O}$-isotope composition of spinel is not useful in discriminating their geographic origin while trace elements are relevant for indicating their mine origin.

\section{Geological setting}

The primary spinel deposits are located in the Himalayan mountain belt which formed during Tertiary collision of the Indian plate northward into the Eurasian plate. They are spatially related to ruby deposits hosted by platform carbonate series metamorphosed to the amphibolite facies (Garnier et al., 2008). The marble units are intercalated generally with biotite-garnet-sillimanite or -kyanite gneisses, and granitoids. Marble paragenesis consists of calcite, dolomite, spinel, forsterite, clinohumite, apatite, margarite, pargasite, chlorite such as sheridanite-clinochlore, \pm graphite, \pm pyrite, \pm pyrrhotite (Garnier et al., 2008). In Vietnam, the primary deposits occur in the Lo Gam tectonic zone in the Thac Ba and An Phu metasedimentary sequences of Cambrian age, comprising marble and overlying biotite-garnet-sillimanite gneiss and schist (Figure 2). The Lo Gam zone is limited by two left-lateral faults which belong to the Red River Shear Zone, and is intruded by granitoids of Triassic age (Garnier et al., 2005). Spinel ( $\mathrm{Spl}$ ) occurs either as crystals disseminated in marble (Figure 3A, C) or impure marbles associated with mostly calcite (Cal) dolomite (Dol), forsterite (Fo), clinohumite (Chu), pargasite (Figure 3E), phlogopite (Phl) and chlorite (Figure 3B, D). Hauzenberger et al. (2001) obtained a minimum temperature of about $700^{\circ} \mathrm{C}$ for the formation of spinel based on the mineral assemblage Chu-Cal-Fo-DolSpl at water-rich fluid composition. Such temperature conditions are different from those defined for gem ruby (Crn) formation 
Vietnam Journal of Earth Sciences, 40(2), 165-177

which occurred during retrograde metamorphism $\left(620<\mathrm{T}<670^{\circ} \mathrm{C}\right.$; Garnier et al., 2008). The main equilibrium reaction between corundum and spinel during prograde metamorphism is the following: $\mathrm{Crn}+\mathrm{Dol} \rightarrow \mathrm{Spl}+\mathrm{Cal}$ $+\mathrm{CO}_{2}$. This reaction explains why gem corundum and spinel are generally not associated in the same outcrop. In addition, in situ $\mathrm{U} / \mathrm{Pb}$ dating of zircons included in spinel from An Phu (Garnier et al., 2005) indicated a crys- tallization age during the Permian (256 Ma) with a reopening of the $\mathrm{U} / \mathrm{Pb}$ system in the Early Triassic (232 Ma). These two ages contrast with the $\mathrm{U} / \mathrm{Pb}$ ages of $38 \mathrm{Ma}$ found for zircons included in ruby from the same area. This discrepancy signifies that at least two metamorphic episodes occurred in the Indochina block before the Himalayan orogeny, and most likely some of the spinels are older than the associated rubies.

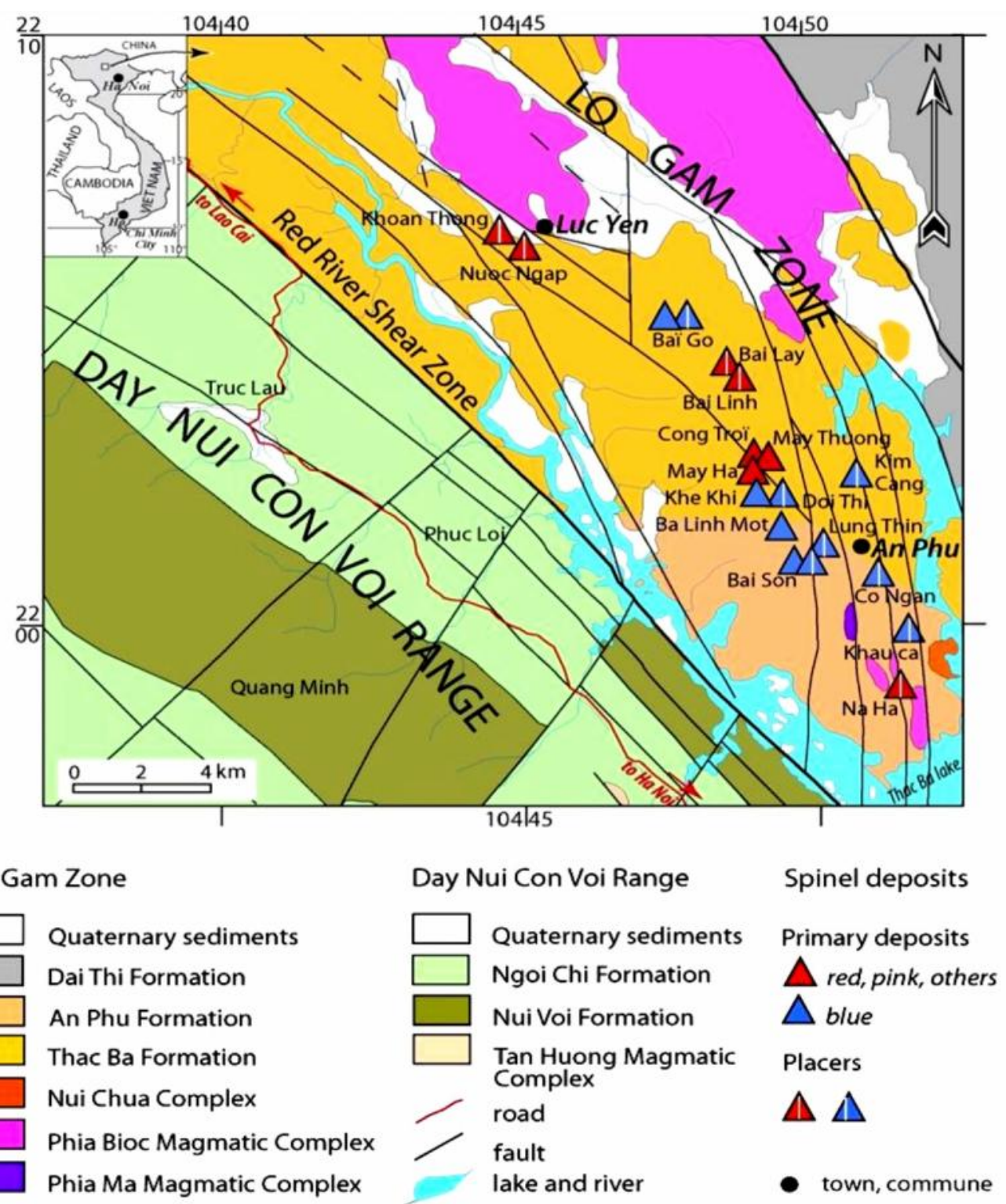

Figure 2. Location of the spinel deposits from the Luc Yen area in northern Vietnam (modified from Garnier 2003) 

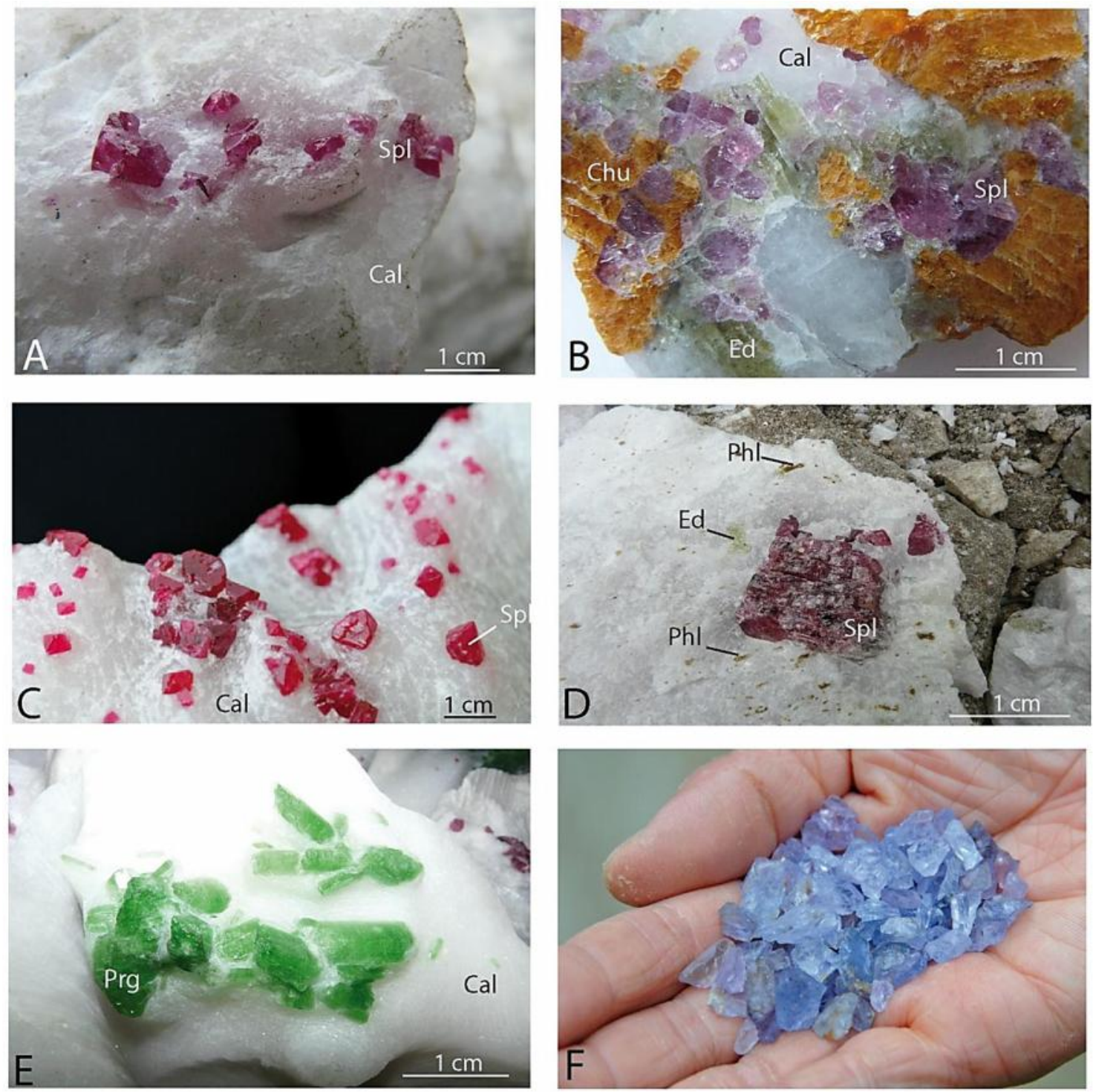

Figure 3. Spinels in marble. A- Pink spinels ( $\mathrm{Spl}$ ) disseminated in a calcitic (Cal) marble from Cong Troi, Luc Yen area. B- Spinel ( $\mathrm{Sp}$ ) associated with clinohumite (Chu), edenite (Ed) in a calcitic marble (Cal) from An Phu quarries. C- Crystals of red spinel around $1 \mathrm{~cm}$ across in a marble from Luc Yen. D- Pinkish spinel associated with phlogopite $(\mathrm{Phl})$ and edenite $(\mathrm{Ed})$ in a marble from Cong Troi. D- Pargasite (Prg) in a saccharoidal marble from An Phu. E- Pale blue spinel from the Luc Yen area. Photographs A-B-D-E: G. Giuliani/IRD; C-F: V. Pardieu/GIA. Mineral abbreviations after Kretz (1983)

\section{Spinel mining activities in Luc Yen district}

Gem spinels, rubies and sapphires were discovered in Luc Yen in 1987 (Pham et al., 2013). Today, the deposits which extend between Luc Yen and An Phu localities are found either in marble or placers (Figure 4).
Primary deposits concern the Cong Troi mining district where spinels occur in different colours (red, pink, brown, violet) and the Bai son mine where spinel is blue. These deposits are characterized by crystals of spinel widespreading in dolomitic marble with 
Vietnam Journal of Earth Sciences, 40(2), 165-177

sometimes a $\mathrm{Ca}$ - and $\mathrm{Mg}$-Si-rich paragenesis such as dolomite, calcite, phlogopite, forsterite, clinohumite and edenite-pargasite (Figure 3), and sulphides and graphite. Spinel, edenite-pargasite and phlogopite are distributed in bands and strips parallel to the foliation

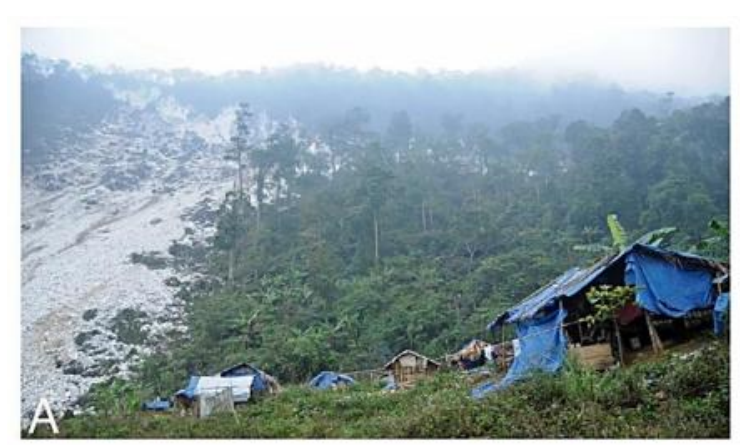

of the marbles. The crystals vary in size from $1 \times 1 \mathrm{~cm}$ to $3 \times 3 \mathrm{~cm}$, and present the common octahedral habit and its red to brownish red colour. The biggest crystals are usually translucent to opaque and are used only as mineralogical collection samples.
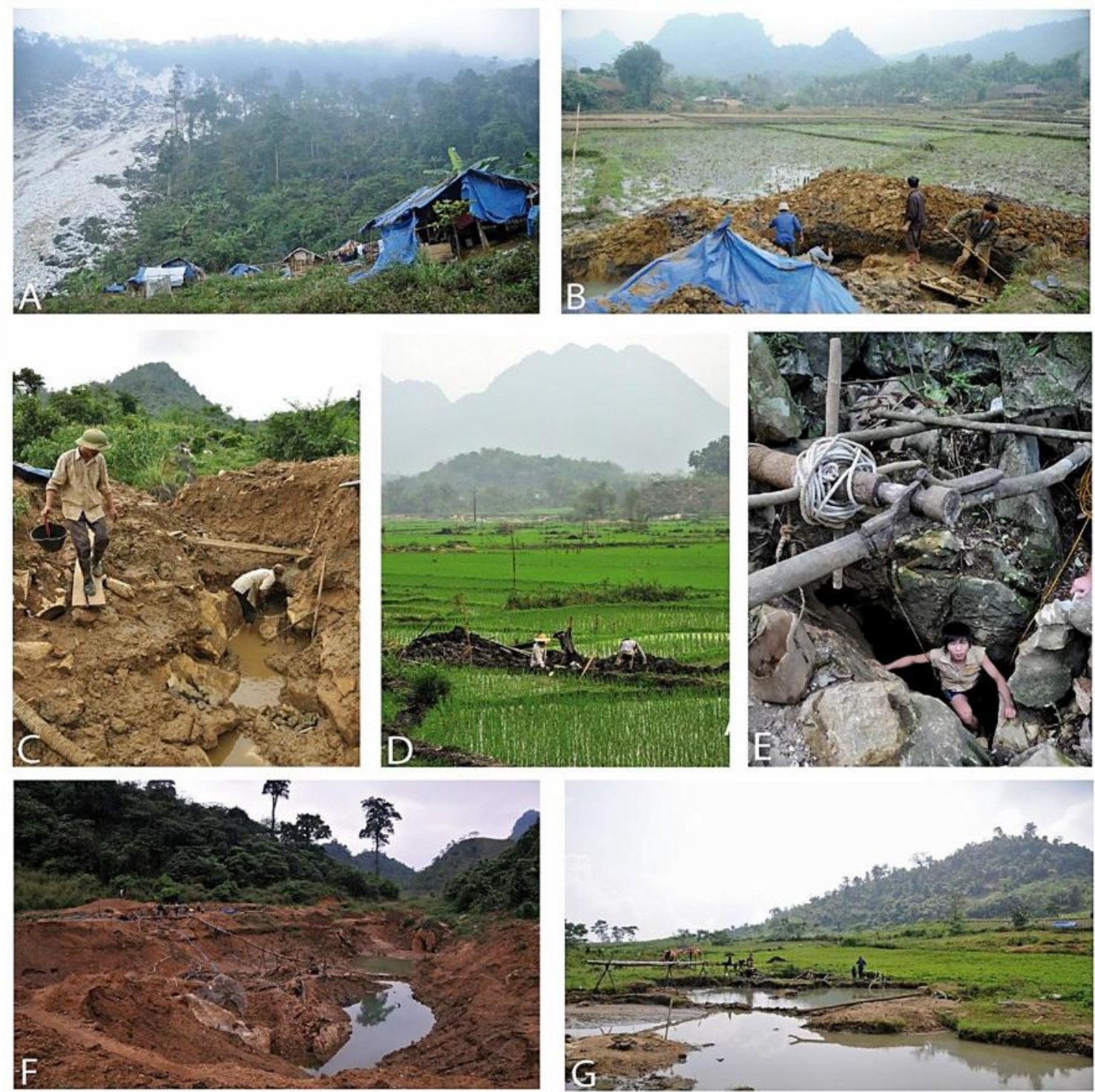

Figure 4. Views of spinel mining in the Luc Yen and An Phu areas.A- The Cong Troi spinel mining quarry and camp. B- Opening of a spinel-bearing alluvial in a rice field. C- Mining spinels in colluvial soil and sediments. DProspecting spinel in a rice field. E- Gem spinel mining in a karst formed in marble. Photographs: V. Pardieu

The spinel and pargasite mining activities are focused in the Cong Troi area since 2000s
(Figure 4A). In 2009-2010, the mining licences in the region were allocated to a local com- 
pany for exploiting white marble intended for export. They started to carry out drilling operations in the area, so the exploitation of gems by local people was suspended up to late 2010. Currently, there are two or three different groups of miners with a total of twenty people are working at the mine site. The spinel mining area is often spread over a large area and covers the whole Cong Troi mountain from the base to the top. The spinels in the Cong Troi area present different colours, but the most common ones are brownish red, reddish brown, brown, purple, pink, and purplish pink. The size varies from $1 \times 1 \mathrm{~mm}$ to 50 $\times 50 \mathrm{~mm}$ (Figure 3A, D). The crystals present the octahedral habit with spinel twin law.

Blue spinel is found in the white marble along Bai Son valleys. The blue spinels from placer are generally of gem quality (Figure 1D), however the blue spinel crystals found in marble are often in dull coloured, of low transparency, and not of gem quality. Spinel is associated with phlogopite, clinohumite and sometimes pyrite. The pargasite crystals present prismatic and elongated shapes. The colour of the amphibole varies from green, light green to yellow green but the crystals are not transparent. They can form groups of crystals with a size between $0.5 \times 2 \mathrm{~cm}$ to $1.5 \times 5 \mathrm{~cm}$.

Placer deposits are mined along the streams or alluvial by local farmers (Figure 4B to D). Spinels are generally of gem-quality and used for gem cutting. They exhibit red, brownish red, pink, purple, sea blue, and sky blue colours (Figure 3F). The red, brownish red and pink spinels are found in An Phu, Minh Tien, and Khoan Thong areas (Figure 2 ), and pink and purple spinels are found in the Cong Troi area. Sea blue spinel is mined in Co Ngan area located at about $5 \mathrm{~km}$ north of An Phu commune and sometimes in Bai Son. Sky blue colour spinel is only found in Bai Son and Lung Thin area in an underground development about 5-8 $\mathrm{m}$ deep, where a blue spinel of $97 \mathrm{cts}$ was recovered.
Mining is carried out along the streams of Cong Troi, Nuoc Ngap (An Phu area) and sometimes in the removing spoil tips of old mining areas such as in Minh Tien, Khoan Thong, Bai Chuoi areas producing light blue spinel. In some places, the local people mined in karst or caves formed in white marbles (Figure 4E; Cong Troi 2, Cong Troi 3, May Thuong and May Ha deposits).

\section{Analytical Techniques}

For this study, 32 crystals of spinels collected from primary and secondary deposits of Cong Troi, An Phu commune, Nuoc Ngap and Bai Son (see Tables 1 and 2 for the type of deposit) were used for examination through EMPA ( $\mathrm{n}=32$, and 220 analysis) and oxygen isotopes analyses $(\mathrm{n}=25)$. Spinel samples were collected by the authors from different field work programs.

EMPA data of the spinels were obtained using the CAMECA SX100 facility at the University of Lorraine, Nancy, France. The operating conditions were the following: accelerating voltage of $15 \mathrm{kV}$ for $\mathrm{Mg}, \mathrm{Al}$ and $\mathrm{Fe}$, beam current $20 \mathrm{nA}$, raster length 0.05 $\mu \mathrm{m}$, collection time $20 \mathrm{~s}$; and accelerating voltage of $25 \mathrm{kV}$ for the other trace elements, beam current $100 \mathrm{nA}$, raster length $0.05 \mu \mathrm{m}$, collection time of $30 \mathrm{~s}$ for $\mathrm{Ti}, \mathrm{Mn}$ and $\mathrm{Zn}$ and $60 \mathrm{~s}$ for $\mathrm{Ca}, \mathrm{V}, \mathrm{Cr}, \mathrm{Co}$ and $\mathrm{Ni}$. Mineral and synthetic standards used were $\mathrm{Mg}$ (olivine), $\mathrm{Al}$ (corundum), $\mathrm{Fe}$ (hematite), $\mathrm{Ti}$ and $\mathrm{Mn}$ (manganese titanite), V (V-SX9 metal), $\mathrm{Cr}$ (chromite), $\mathrm{Co}$ (Co metal), $\mathrm{Ni}$ (NiO alloy) and $\mathrm{Zn}$ (sphalerite). The detection limits for trace elements in mass percentage ratio (ppm) were 37 for Ti, 60 for $\mathrm{V}, 30$ for $\mathrm{Cr}, 130$ for $\mathrm{Mn}, 90$ for $\mathrm{Co}$ and $\mathrm{Ni}$, and 180 for $\mathrm{Zn}$. Data reduction was performed with the PAP program (Pouchou and Pichoir, 1991).

Oxygen isotope analyses were performed on different coloured spinels at S.U.E.R.C Glasgow (Scotland) using a modification of the laser-fluorination technique (see Giuliani et al., 2005). Data are reported in the conventional $\delta^{18} \mathrm{O}$ notation as per mil $(\%)$ relative to 
Vietnam Journal of Earth Sciences, 40(2), 165-177

the Vienna Standard Mean Ocean Water (VSMOW).

\section{Results}

\subsection{EMPA analysis}

Representative EMPA data of spinels are reported in Table 1. The highest concentrations in trace elements were obtained for $\mathrm{Cr}$, $\mathrm{V}, \mathrm{Fe}$ and $\mathrm{Zn}$ whereas $\mathrm{Ti}$ and $\mathrm{Mn}$ contents were low to very low and sometimes below the detection limits. Co and Ni were only detected in blue spinels. The chemical variations between pink to red spinels (variety 1) with other colours (variety 2) will be examined separately.

Variety 1: The pink and red spinels are characterized by the presence of $\mathrm{Fe}, \mathrm{Cr}$ and $\mathrm{V}$. $\mathrm{Zn}$ is not a chromophore but its concentration is very high for some spinels from An Phu (up to $11,000 \mathrm{ppm}$ ). The $\mathrm{Zn}$ vs. Fe diagram discriminates the spinels from Cong Troi from those of An Phu and Nuoc Ngap (Figure 5). The spinels from Cong Troi are Fe-rich and
Zn-poor. They show a vertical trend starting from 3,000 and going up to $16,000 \mathrm{ppm}$ of $\mathrm{Fe}$ but with very low $\mathrm{Zn}$ contents $(\mathrm{Zn}<500 \mathrm{ppm})$. On the contrary, the An Phu spinels present four chemical fields. They are $\mathrm{Zn}$-rich and with Fe values between 4,000 and 11,000 ppm.

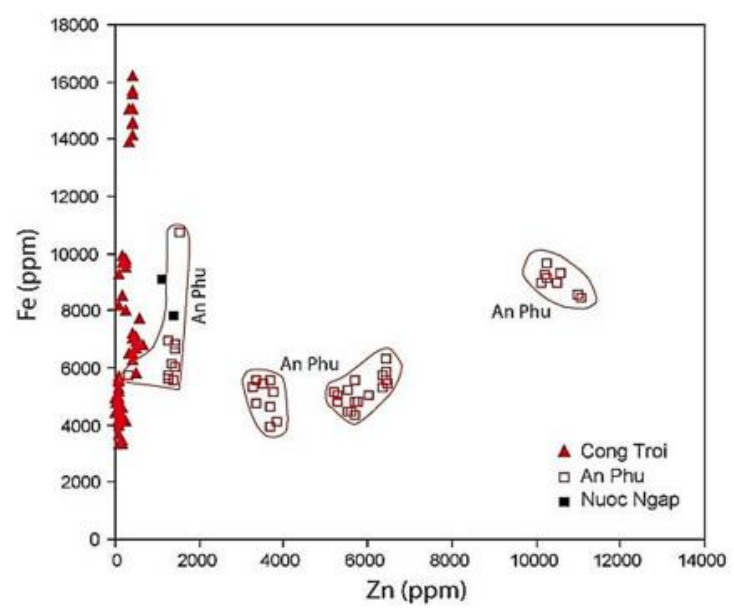

Figure 5. Zn vs. Fe (in ppm) diagram for pink and red spinels from the mining sites of Cong Troi, An Phu and Nuoc Ngap

Table 1. Representative electron microprobe analyses of pink, red and coloured spinels from An Phu, Cong Troi, Bai Son and Nuoc Ngap deposits

\begin{tabular}{|c|c|c|c|c|c|c|c|c|c|c|c|c|c|c|}
\hline Deposit & Type of & Sample & Colour & $\mathrm{MgO}$ & $\mathrm{Al}_{2} \mathrm{O}_{3}$ & $\mathrm{FeO}$ & $\mathrm{TiO}_{2}$ & $\mathrm{~V}_{2} \mathrm{O}_{3}$ & $\mathrm{Cr}_{2} \mathrm{O}_{3}$ & $\mathrm{MnO}$ & $\mathrm{ZnO}$ & $\mathrm{CoO}$ & $\mathrm{NiO}$ & Total \\
\hline & deposit & & \multicolumn{12}{|c|}{ (weight \%) } \\
\hline \multirow[t]{10}{*}{ An Phu } & primary & $\mathrm{AP} 4$ & red & 27.64 & 70.86 & 0.57 & 0.00 & 0.00 & 0.18 & 0.00 & 0.04 & 0.00 & 0.00 & 99.29 \\
\hline & placer & VIET1 & red & 27.55 & 70.25 & 0.55 & 0.02 & 0.37 & 1.15 & 0.00 & 0.80 & 0.00 & 0.00 & 100.69 \\
\hline & $"$ & VIET2 & pale red & 27.56 & 71.10 & 0.41 & 0.02 & 0.52 & 0.12 & 0.00 & 0.48 & 0.00 & 0.00 & 100.21 \\
\hline & $"$ & VIET3 & red & 27.92 & 70.64 & 0.92 & 0.00 & 0.10 & 0.23 & 0.01 & 1.27 & 0.00 & 0.00 & 101.08 \\
\hline & $"$ & VIET8 & pale pink & 28.34 & 70.91 & 0.48 & 0.01 & 0.16 & 0.17 & 0.00 & 0.66 & 0.00 & 0.00 & 100.73 \\
\hline & $"$ & ANP5 & lavender & 27.77 & 71.61 & 0.66 & 0.01 & 0.05 & 0.05 & 0.01 & 0.12 & 0.00 & 0.00 & 100.28 \\
\hline & $"$ & VIET23 & purple & 27.39 & 71.69 & 0.79 & 0.00 & 0.00 & 0.00 & 0.01 & 0.32 & 0.00 & 0.00 & 100.20 \\
\hline & & & to brown & & & & & & & & & & & \\
\hline & placer & VIET24 & $\begin{array}{l}\text { purple } \\
\text { to brown }\end{array}$ & 25.97 & 71.89 & 3.41 & 0.00 & 0.01 & 0.10 & 0.02 & 0.05 & 0.00 & 0.00 & 101.5 \\
\hline & placer & VIET27 & $\begin{array}{l}\text { brownish to } \\
\text { orange }\end{array}$ & 27.74 & 71.46 & 0.57 & 0.01 & 0.01 & 0.57 & 0.09 & 0.28 & 0.00 & 0.00 & 100.7 \\
\hline \multirow[t]{11}{*}{ Cong Troi } & placer & VIET9 & pink & 27.36 & 72.62 & 0.97 & 0.00 & 0.00 & 0.01 & 0.00 & 0.02 & 0.00 & 0.00 & 100.98 \\
\hline & primary & CT1 & pink & 28.54 & 70.75 & 0.50 & 0.01 & 0.20 & 0.06 & 0.01 & 0.00 & 0.00 & 0.00 & 100.13 \\
\hline & $"$ & CT4 & pink & 28.12 & 70.34 & 1.41 & 0.02 & 0.52 & 0.10 & 0.01 & 0.05 & 0.00 & 0.00 & 100.71 \\
\hline & $"$ & VIET31 & pink & 27.70 & 71.83 & 0.41 & 0.02 & 0.25 & 0.18 & 0.00 & 0.01 & 0.00 & 0.00 & 100.41 \\
\hline & $"$ & VIET33 & pink & 27.43 & 71.32 & 0.58 & 0.00 & 0.04 & 1.13 & 0.02 & 0.06 & 0.00 & 0.00 & 100.58 \\
\hline & $"$ & VIET1 & pale purple & 28.97 & 71.27 & 0.48 & 0.00 & 0.09 & 0.01 & 0.01 & 0.00 & 0.00 & 0.00 & 100.9 \\
\hline & placer & VIET11 & purple & 28.33 & 70.58 & 0.57 & 0.01 & 0.17 & 0.51 & 0.00 & 0.67 & 0.00 & 0.00 & 100.8 \\
\hline & $"$ & VIET14 & purple & 28.41 & 71.55 & 0.73 & 0.00 & 0.06 & 0.02 & 0.00 & 0.00 & 0.00 & 0.00 & 100.8 \\
\hline & $"$ & VIET15 & deep purple & 27.03 & 70.95 & 1.58 & 0.00 & 0.00 & 0.01 & 0.01 & 1.31 & 0.00 & 0.00 & 100.9 \\
\hline & $"$ & VIET16 & pale purple & 28.89 & 72.19 & 0.39 & 0.00 & 0.03 & 0.01 & 0.00 & 0.00 & 0.00 & 0.00 & 101.5 \\
\hline & primary & VIET32 & dark brown & 28.10 & 70.88 & 1.45 & 0.02 & 0.41 & 0.09 & 0.01 & 0.00 & 0.00 & 0.00 & 101.0 \\
\hline \multirow[t]{3}{*}{ Bai Son } & placer & VIET19 & pale blue & 27.52 & 72.36 & 0.75 & 0.00 & 0.00 & 0.01 & 0.00 & 0.34 & 0.00 & 0.00 & 101.0 \\
\hline & $"$ & VIET20 & purple & 28.10 & 71.13 & 0.90 & 0.01 & 0.14 & 0.07 & 0.00 & 0.00 & 0.00 & 0.00 & 100.4 \\
\hline & $"$ & VIET21 & blue & 27.88 & 72.95 & 0.51 & 0.01 & 0.14 & 0.07 & 0.01 & 0.02 & 0.05 & 0.12 & 101.8 \\
\hline \multirow[t]{2}{*}{ Nuoc Ngap } & placer & V41a1 & pinkish & 27.14 & 71.11 & 0.91 & 0.02 & 0.01 & 0.01 & 0.09 & 0.12 & 0.00 & 0.00 & 99.41 \\
\hline & " & V41a2 & pink & 26.56 & 71.89 & 0.78 & 0.02 & 0.02 & 0.01 & 0.10 & 0.17 & 0.00 & 0.00 & 99.53 \\
\hline
\end{tabular}


The $\mathrm{FeO}-\mathrm{Cr}_{2} \mathrm{O}_{3}$ vs. $2 \mathrm{ZnO}+\mathrm{V}_{2} \mathrm{O}_{3}$ diagram (Figure 6A) shows that the chemical fields of spinels from Cong Troi and Nuoc Ngap plot mainly in the $\mathrm{Fe}>\mathrm{Cr}$ and $\mathrm{V}>\mathrm{Zn}$ boxes. Some samples of Cong Troi and An Phu plot in the box of $\mathrm{Fe}<\mathrm{Cr}$. The Cong Troi spinels have higher $\mathrm{Cr}$ (between 70 and 9,000 ppm) than $\mathrm{V}$ (between 70 to $3,670 \mathrm{ppm}$ ). The ternary diagram Fe-V-Zn (Figure 7A) corroborates these different chemical trends and also discriminates their geographic origin. The ternary diagram $\mathrm{Cr}-\mathrm{V}-\mathrm{Zn}$ (Figure 7B) confirms the chemical differences between spinels from Cong Troi, An Phu and Nuoc Ngap.
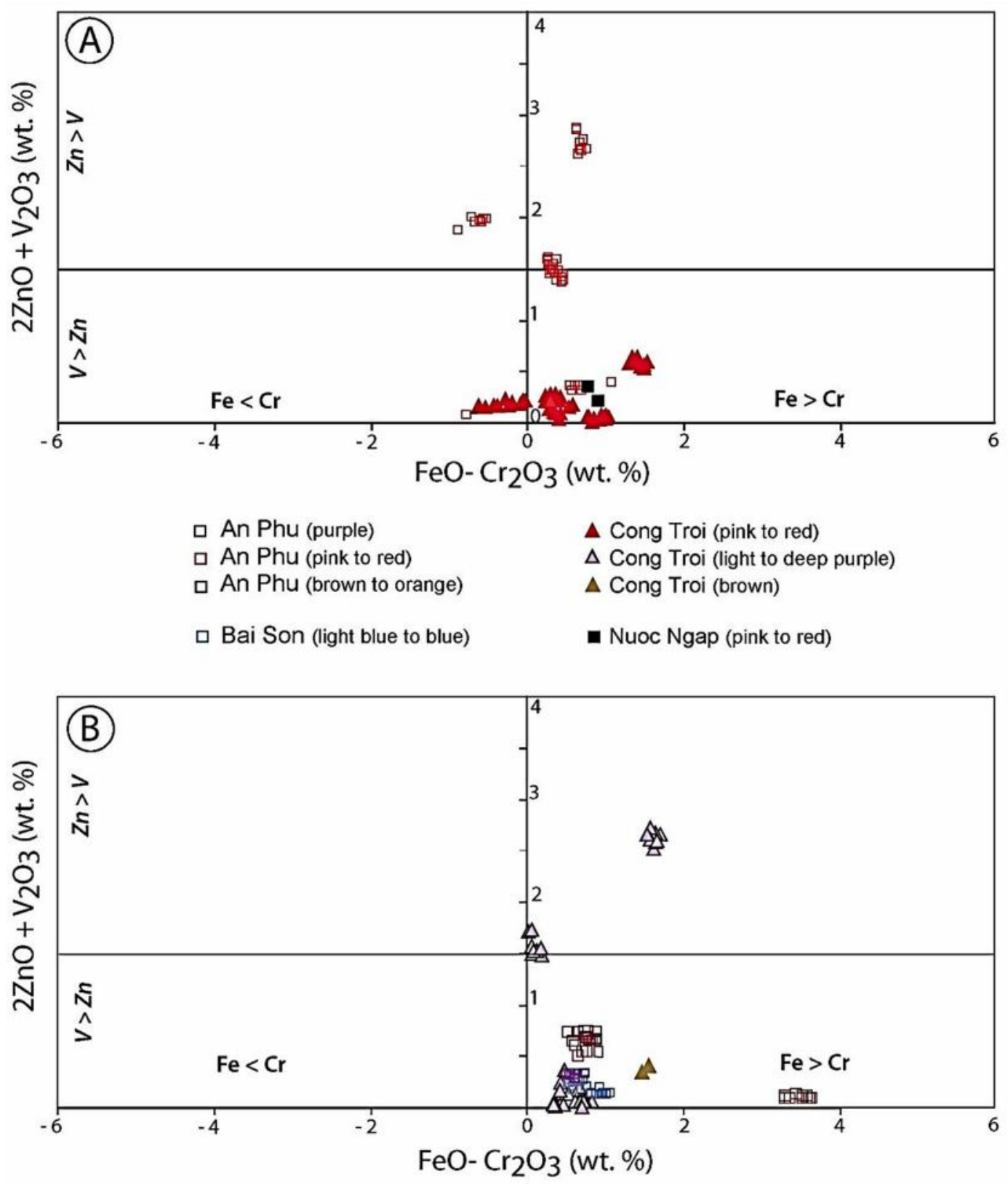

Figure 6. $\mathrm{FeO}-\mathrm{Cr}_{2} \mathrm{O}_{3}$ vs. $2 \mathrm{ZnO}+\mathrm{V}_{2} \mathrm{O}_{3}$ (in wt \%) diagram for A: pink and red spinels, and $\mathrm{B}$ : other coloured spinels from Cong Troi, An Phu, Nuoc Ngap and Bai Son mines 


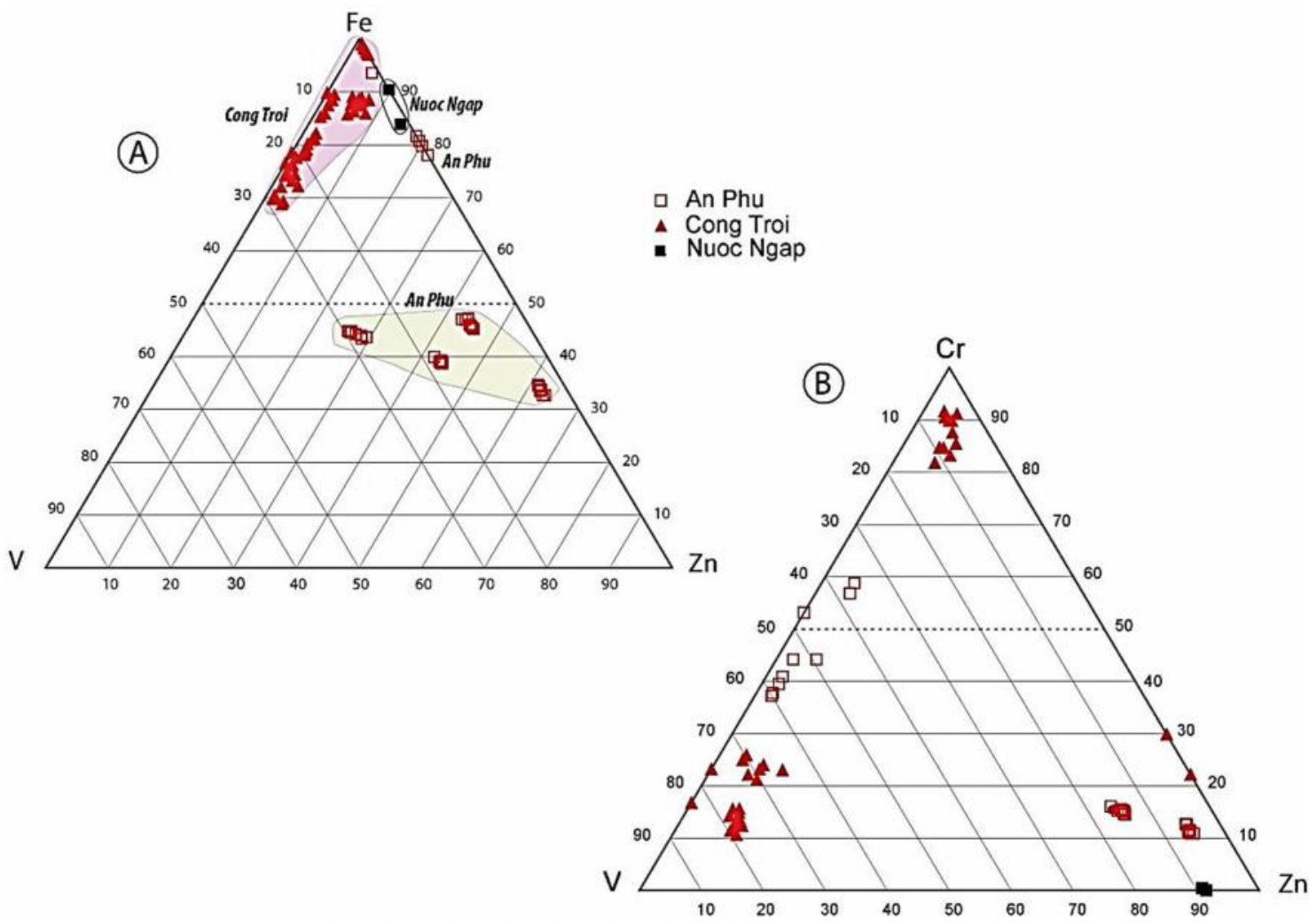

Figure 7. Chemical ternary diagrams for pink and red spinels from Cong Troi, An Phu and Nuoc Ngap. A: Fe-V-Zn ternary diagram that discriminates amongst the different deposits. B: $\mathrm{Cr}-\mathrm{V}-\mathrm{Zn}$ ternary diagram for each spinel deposit

Variety 2: The chemical compositions of coloured spinel reported in Table 1 are presented in Figure 6B. Iron is the dominant element whereas $\mathrm{Zn}, \mathrm{Cr}$ and $\mathrm{V}$ contents are extremely variable. The Bai Son blue spinel is Fe-rich $(5,000$ to $7,200 \mathrm{ppm})$ with some V (950 to $1,830 \mathrm{ppm}), \mathrm{Cr}$ (270 to $480 \mathrm{ppm}$ ), Co (240 to $400 \mathrm{ppm}$ ) and $\mathrm{Ni}(550$ to $950 \mathrm{ppm})$. Purple spinels from An Phu are characterized by $\mathrm{Fe}>\mathrm{Zn}>\mathrm{V}>\mathrm{Cr}$ whereas light to deep purple ones from Cong Troi are Fe-rich but with extreme variation in $\mathrm{Zn}$ (a few to 10,100 ppm), and with $\mathrm{Cr}$ up to $6,350 \mathrm{ppm}$ and $\mathrm{V}$ up to $1,300 \mathrm{ppm}$. Brown to orange spinels from An Phu have $\mathrm{Fe}>\mathrm{Zn}$ with extremely variable $\mathrm{Cr}$ and $\mathrm{V}$ contents (Table 2) whereas dark brown spinels from Cong Troi are $\mathrm{Zn}$-free but with concentrations in $\mathrm{Fe}, \mathrm{V}$ and $\mathrm{Cr}$ of respectively, 14,500, 2,800 and $600 \mathrm{ppm}$.

\subsection{Oxygen isotope analyses}

The O-isotope composition of Vietnamese spinels from primary and secondary deposits ranges between 12.1 and $24.2 \%$ o $(n=32$; Table 2). Spinels can be classified heuristically into tw odistinct sets of $\delta^{18} \mathrm{O}$ values (Figure 8):

(i) The first $\delta^{18} \mathrm{O}$ set, between 12.1 and 18.6\%o ( $\mathrm{n}=19$ ) includes red, pink and coloured spinels: (i) the pink and red spinels from the primary and placer deposits of Cong Troi and An Phu have $\delta^{18} \mathrm{O}$ values in the range of respectively, 14.7 to $17.7 \%$ o $(n=3)$ and 13.2 to $17 \%$ o $(n=7)$; (ii) the other coloured spinels from Cong Troi have $\delta^{18} \mathrm{O}$ values between 15.5 and $18.6 \%$ o $(n=3)$ whereas those of An Phu are in the range $14.2 \%$ o to $14.9 \%$ o (n $=4)$. The Bai Son blue dark spinel has a relatively low O-isotopic composition of $12.1 \%$. 
(ii) Spinels from the second set of $\delta^{18} \mathrm{O}$ value sare characterized by higher values (19 $<\delta^{18} \mathrm{O}<24.2 \%$, $\mathrm{n}=13$ ): (i) the pink to red spinels from An Phu $\left(22.5<\delta^{18} \mathrm{O}<24.2, \mathrm{n}=\right.$ 5); (ii) the coloured spinels, either orangey or brown, from An Phu have a $\delta^{18} \mathrm{O}$ range between 21.2 and $24.1 \%$ o $(n=5)$. The Bai Son light blue and purplish spinels have O-isotopic values in the range 19.4 to $22.7(n=2)$ and a single Cong Troi purple spinel has a value of $22.6 \%$.

\section{Discussions}

The use of trace elements such as Fe, Zn, $\mathrm{Cr}$ and $\mathrm{V}$ allowed to characterize the geographic origin i.e. the mine locality or mining district,of the red and pink spinels (variety 1 ) from Cong Troi, An Phu and Nuoc Ngap (Figure 6A and 7A). The low to extremely low $\mathrm{Zn}$ content of the Cong Trois pinels is a discriminant compared to other deposits. On the contrary, the O-isotope composition of spinels is not useful for geographical origin determination because the range of $\delta^{18} \mathrm{O}$ values from Cong Troi (14.7 to $17.7 \%$, $\mathrm{n}=3$ ) overlaps the first range of $\delta^{18} \mathrm{O}$ values from An Phu (13.2 to $17.0 \%$ o, $n=7$ ).

As regards spinels of variety 2 , they are Fe-rich $(\mathrm{Fe}>\mathrm{Cr})$ and present variation in the content of $\mathrm{Zn}$ and $\mathrm{V}$. To the contrary of variety 1 , the spinels from Cong Troi are enriched in $\mathrm{Zn}$ and $\mathrm{V}$ (with $\mathrm{Zn}>\mathrm{V}$ ) while those of An Phu are depleted (with $\mathrm{V}>\mathrm{Zn}$ ).

The blue spinels from Bai Son have a chemical field that is similar to the purple ones from An Phu or Cong Troi (with $\mathrm{V}>\mathrm{Cr}$ ) but they contain $\mathrm{Co}$ and $\mathrm{Ni}$. The spinels present highly variable O-isotope compositions between 12.7 and 22.7\%o. Chauviré et al.(2015) assumed that the cobalt blue colour is due predominantly to $\mathrm{Co}^{2+}$ substituting for $\mathrm{Mg}^{2+}$ in the spinel structure even if iron is more abundant. To the contrary, shades of paler blue in spinel with insignificant Co contents are due to electronic transitions in $\mathrm{Fe}$ (D'Ippolitoet al., 2015). Huong et al.,2012) have shown that: (i) $\mathrm{Co}^{2+}$ and $\mathrm{Cr}^{3+}$ were located in the octahedral site of $\mathrm{Al}^{3+}$ in the spinel structure; and (ii) $\mathrm{Co}^{2+}, \mathrm{Fe}^{2+}$ and $\mathrm{Cr}^{3+}$ ions contributed to colour variation.

Within each deposit, the range of $\delta^{18} \mathrm{O}$ values for red, pink and coloured spinels is similar indicating that $\mathrm{O}$-isotope compositions are independent of the nature of the chemical elements incorporated in the spinel structure. The $\delta^{18} \mathrm{O}$ values of spinel from variety 2 overlap those of variety 1 for An Phu and Cong Troi (Figure 8), except for one purple spinel of Cong Troi which has a $\delta^{18} \mathrm{O}$ value of $22.6 \%$.

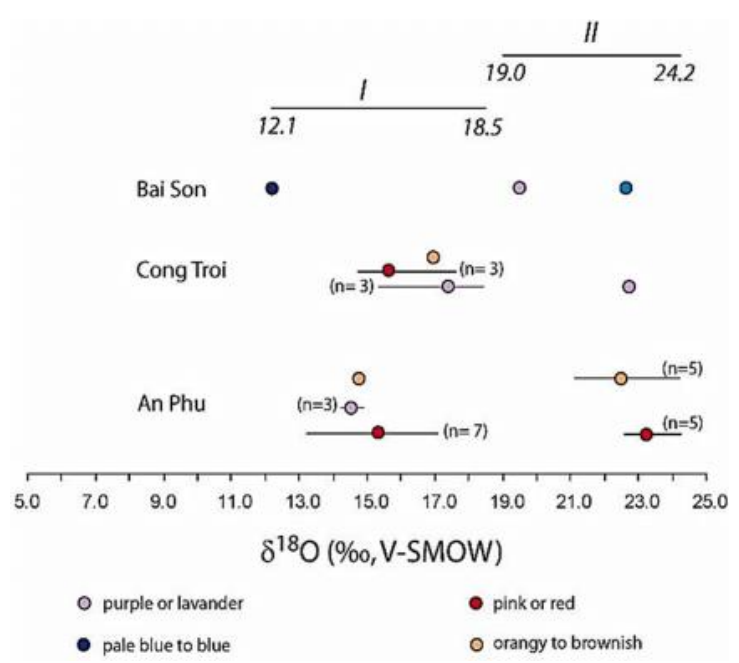

Figure 8. Distribution of the $\delta^{18} \mathrm{O}$ values (\%o, VSMOW) of spinels in marble from the Cong Troi, An Phu and Bai Son deposits. Numbers enclosed in parentheses are the number of analyses

Spinels are considered to be of metamorphic origin (Hauzenberger et al., 2001; 2014; Garnier 2003; Giuliani et al., 2017) but their Oisotope composition is highly variable (12.1 $<\delta^{18} \mathrm{O}<24.2 \%$ o). Spinel is either disseminated in the marble or associated with other minerals such as clinohumite, phlogopite, pargasite, chlorite (Table 2) but the $\delta^{18} \mathrm{O}$ value of spinel is independent of the colour of the crystal and the nature of its paragenesis. The O-isotope variability is probably related to the initial Oisotopic composition of the host marble. The 
Vietnam Journal of Earth Sciences, 40(2), 165-177

$\delta^{18} \mathrm{O}$ values for spinel (and/or ruby)-bearing marbles from the Lo Gam zone range between 18 and 27.1\%o (Garnier, 2003; Garnier et al., 2008). The depletion in oxygen-isotope values for the majority of these marbles cannot be related to batch or Rayleigh decarbonation processes of marble during metamorphism, because the observed isotopic variations are too large (see the discussion in Valley, 1986). It is more likely that the O-isotope heterogeneity of the impure marbles is linked to their heterogeneous compositional chemistry and oxygen isotopic ratios acquired during sedimentation and diagenesis of the protolith. Additionally, the study of Yuiet al. (2008) has shown that the O-isotope fractionation $\delta^{18} \mathrm{O}_{\text {(cc-sp) }}$ between coexisting calcite and spinel, at Mogok in Myanmar, was 3.1 and $4.0 \%$ ( $\mathrm{n}=2$ samples). Such O-isotope fractionation between calcite and spinel could explain the observed variation of O-isotopes for these spinels and current study on spinel in marbles worldwide indicates that the O-isotope fractionation is around $3.6 \%$ o (manuscript in preparation).

Table 2. Oxygen isotope composition (in \%o, V-SMOW) accompanied by the $\mathrm{V} / \mathrm{Cr}$ ratio and $\mathrm{Zn}$ content of spinels from An Phu, Cong Troi and Bai Son deposits

\begin{tabular}{|c|c|c|c|c|c|c|c|}
\hline \multirow{3}{*}{ Deposit } & Type of & \multirow{3}{*}{ Sample } & \multirow{3}{*}{ Colour } & Mineral assemblage & $\mathrm{d}^{18} \mathrm{O}$ & \multirow{3}{*}{$\mathrm{V} / \mathrm{Cr}$} & $\mathrm{Zn}$ \\
\hline & \multirow{2}{*}{ deposit } & & & \multirow{2}{*}{ in the marble } & (V-SMOW) & & \multirow{2}{*}{ (ppm) } \\
\hline & & & & & $(\%)$ & & \\
\hline \multirow[t]{17}{*}{ An Phu } & alluvial & ANP1 & reddish & & 14.3 & na & na \\
\hline & $"$ & ANP2 & reddish to pinkish & & 16.2 & " & $"$ \\
\hline & $"$ & ANP3 & pink & & 14.4 & $"$ & $"$ \\
\hline & $"$ & ANP4 & pinkish & & 13.2 & $"$ & $"$ \\
\hline & $"$ & ANP5 & lavender & & 14.5 & 0.97 & 1080 \\
\hline & $"$ & VIET1 & red & & 23.8 & 0.31 & 6358 \\
\hline & $"$ & VIET2 & pale red & & 22.5 & 5.26 & 3588 \\
\hline & $"$ & VIET3 & red & & 22.8 & 0.47 & 10,488 \\
\hline & $"$ & VIET5 & light red & & 15.3 & - & 1390 \\
\hline & $"$ & VIET7 & pale pink & & 24.2 & na & na \\
\hline & $"$ & VIET8 & pale pink & & 22.9 & 0.96 & 5543 \\
\hline & $"$ & VIET23 & purple to brown & & 22.4 & 0.03 & 2624 \\
\hline & $"$ & VIET24 & purple to brown & & 21.3 & 0.09 & 362 \\
\hline & $"$ & VIET27 & brownish to orange & & 24.1 & 0.02 & 2162 \\
\hline & $"$ & VIET28 & brownish to orange & & 21.2 & na & na \\
\hline & $"$ & VIET29 & dark orange & & 22.9 & $"$ & $"$ \\
\hline & $"$ & VIET30 & dark orange & & 14.8 & $"$ & $"$ \\
\hline \multirow[t]{4}{*}{ An Phu } & primary & Apa & deep purple & pargasite, clinohumite & 14.9 & $"$ & $"$ \\
\hline & $"$ & AP2 & pale purple & forsterite, edenite, graphite & 14.2 & $"$ & $"$ \\
\hline & $"$ & AP4 & red & edenite & 16.8 & 0.03 & 321 \\
\hline & $"$ & V41a & pale pink & pyrite, graphite & 17.0 & na & na \\
\hline \multirow[t]{8}{*}{ Cong Troi } & placer & VIET9 & pink & & 17.7 & - & 175 \\
\hline & $"$ & VIET11 & purple & & 22.6 & 0.31 & 5632 \\
\hline & $"$ & VIET14 & purple & & 15.5 & 5.81 & 0 \\
\hline & $"$ & VIET15 & purple & & 18.5 & 0.10 & 10,560 \\
\hline & $"$ & VIET16 & pale purple & & 18.6 & 2.90 & 0 \\
\hline & primary & VIET31 & pale pink & no associated mineral & 14.7 & 1.2 & 72 \\
\hline & $"$ & VIET32 & dark brown & clinohumite & 17.0 & 5.54 & 40 \\
\hline & $"$ & VIET33 & red & no associated mineral & 14.8 & 0.08 & 460 \\
\hline \multirow[t]{3}{*}{ Bai Son } & placer & VIET19 & pale blue & & 22.7 & - & 2624 \\
\hline & $"$ & VIET20 & purple & & 19.4 & 1.81 & 0 \\
\hline & $"$ & VIET21 & blue & & 12.1 & 5.28 & 102 \\
\hline
\end{tabular}

\section{Conclusions}

The EMPA and oxygen isotope ratio analyses of gem spinels from Luc Yen -An Phu areas have shown that: (i) the use of trace el- ements such as $\mathrm{Fe}-\mathrm{Zn}-\mathrm{Cr}-\mathrm{V}$ in red and pink gem spinels permits to discriminate the geographic origin of Cong Troi and An Phu deposits; (ii) on the contrary, the O-isotope composition of spinels is not useful in this re- 
gard. Indeed, the $\delta^{18} \mathrm{O}$ range of values for spinels from Cong Troi overlaps that of An Phu but the low to extremely low $\mathrm{Zn}$ and high $\mathrm{Fe}$ contents of spinels from Cong Troi compared to An Phu permit to discriminate these two main Vietnamese deposits; (iii) the variation of $\delta^{18} \mathrm{O}$ values $\left(12.1<\delta^{18} \mathrm{O}<24.2 \%\right.$ o of spinel indicates that the oxygen isotopic composition of the metamorphic fluids were probably buffered by the local $\delta^{18} \mathrm{O}$ values of the impure host marbles.

Future work combining more analysis of trace elements and O-isotopes on spinels from Cong Troi with its considerable quantity of blue spinels, An Phu and other Vietnamese deposits will improve the preliminary chemical and O-isotope database presented in this work.

\section{Acknowledgements}

The authors thank the Institut de Recherche pour le Développement (UPS-GET/IRD, Toulouse, France) and the University of Lorraine (UL-CRPG/CNRS, Nancy, France) for the financial support for field and laboratory works. We thank Prof. Lee Groat, ChiefEditor of the journal The Canadian Mineralogist, for authorizing us to use the data relative to the Vietnamese spinels, already published in a paper from The Canadian Mineralogist, for writing the present work for the Vietnam Journal of Earth Sciences. This paper is supported by NAFOSTED of Vietnam, code 105.02-2010.11.

\section{References}

Chauviré B., Rondeau B., Fritsch E., Ressigeac Ph., Devidal J.-L., 2015. Blue spinel from the Luc Yen district of Vietnam. Gems \& Gemology, 51, 2-17.

D’Ippolito V., Andreozzi G.B., Hålenius H., Skogby H., Hametner K., Günther D., 2015. Colour mechanisms in spinel: cobalt and iron interplay for the blue colour. Physics and Chemistry of Minerals, 42, 431-439.

Garnier V., 2003. Les gisements de rubis associés aux marbres de l'Asie Centrale et du Sud-est: genèse et caractérisation isotopique. $\mathrm{PhD}$ thesis INPL, Nancy, France, 373p.

Garnier, V., Ohnenstetter, D., Giuliani, G., Maluski, H., Deloule, E., Phan Trong Trinh, Pham Van Long, Hoang Quang Vinh, 2005. Age and significance of ruby-bearing marbles from the Red River shear zone, northern Vietnam. The Canadian Mineralogist, 43, 1315-1329.

Garnier V., Giuliani G., Ohnenstetter D., Fallick A.E., Dubessy J., Banks D., Hoang Quang Vinh, Lhomme Th., Maluski H., Pêcher A., Bakhsh K.A., Pham Van Long, Phan Trong Trinh, Schwarz D., 2008. Marblehosted ruby deposits from central and Southeast Asia: towards a new genetic model. Ore Geology Reviews, 34, 169-191.

Giuliani G., Fallick A.E., Garnier V., France-Lanord Ch., Ohnenstetter D., Schwarz D., 2005. Oxygen isotope composition as a tracer for the origins of rubies and sapphires. Geology, 33(4), 249-252.

Giuliani G., Fallick A.E., Boyce A.J., Pardieu V., Pham Van Long, 2017. Pink and red spinels in marble: trace elements, oxygen isotopes, and sources. The Canadian Mineralogist, 55, 743-761.

Hauzenberger C.A., Häeger T., Baumgartner L.P., Hofmeister W., 2001. High-grade metamorphism and stable isotope geochemistry of N-Vietnamese gembearing rocks. In: Proceedings of the Workshop on gems and minerals of Vietnam, Hanoi, 124-138.

Hauzenberger C.A., Bagola C., Häeger T., Muellen C., Nguyen Ngoc Khoi, Le Thi Thu Huong, 2014. Mineralogy and petrology of the An Phu marble hosted spinel and corundum deposit, Luc Yen, N-Vietnam. In Proceedings of the $4^{\text {th }}$ International Gem and Jewelry Conference, Chiang Mai, Thailand, 76-78.

Kleišmantas A., Daukšyte A., 2016. The influence of Vietnam and Sri Lanka spinel mineral chemical elements on colour. Chemija, 27, 45-51.

Kretz R., 1983. Symbols for rock-forming minerals. American Mineralogist, 68, 277-279.

Le Thi Thu Huong, Häeger T., Hofmeister W., Hauzenberger C., Schwarz D., Pham Van Long, Wehmeister U., Nguyen Ngoc Khoi, Nguy Tuyet Nhung, 2012. Gemstones from Vietnam: An update. Gems \& Gemology, 48, 158-176. 
Vietnam Journal of Earth Sciences, 40(2), 165-177

Malsy A., Klemm L., 2010. Distinction of gem spinels from the Himalayan mountain belt. Chimia, 64(10), 741-746.

Malsy A., Karampelas S., Schwarz D., Klemm L., Armbruster T., Tuan Do Anh, 2012. Orangey-red to orangey-pink gem spinels from a new deposit at Lang Chap (Tan Huong - Truc Lau), Vietnam. The Journal of Gemmology, 33, 19-27.

Pham Van Long, Hoang Quang Vinh, Garnier V., Giuliani G., Ohnenstetter D., Lhomme,T., Schwarz D., Fallick A.E., Dubessy J., Phan Trong Trinh, 2004. Gem corundum deposits in Vietnam. Journal of Gemmology, 29, 129-147.

Pham Van Long, Pardieu V., Giuliani G., Nguy Tuyet Nhung, Pham Thi Thanh Hien, Pham Duc Anh, Nguyen Ngoc Khoi, Hoang Quang Vinh, 2014.
Gemmological characteristics of spinel from Luc Yen, Yen Bai. Journal of Geology, 340, 29-36.

Pham Van Long, Pardieu V., Giuliani G., 2014. Update on gemstone mining in Luc Yen, Vietnam. Gems \& Gemology, 49, 233-245.

Pouchou J.L., Pichoir F., 1991. Quantitative analysis of homogeneous or stratified microvolumes applying "PAP" In Electron Probe Quantification (K.F.J. Heinrich \& D.E. Newbury eds.). Plenum Press, New York, USA, 31-75.

Valley J.W., 1986. Stable isotope geochemistry of metamorphic rocks. Reviews in Mineralogy, 16, 445-481.

Yui T.F., Khin Zaw, Wu C.-M., 2008. A preliminary stable isotope study on Mogok ruby, Myanmar. Ore Geology Reviews, 34, 182-199. 